\title{
The Phenomenon of Marriage Couples with Long-Distance Relationship
}

\author{
${ }^{1}$ JENNY RATNA SUMINAR, ${ }^{2}$ SITI MURNI KADDI \\ ${ }^{1}$ Fakultas Ilmu Komunikasi Universitas Padjadjaran, Jatinangor-Sumedang Jawa Barat, ${ }^{2}$ Fakultas Ilmu Sosial dan \\ Ilmu Politik Universitas Tadulako, Palu, Sulawesi Tengah. \\ email: ${ }^{1}$ jenny.suminar@unpad.ac.id; ${ }^{2}$ unni_kaddi@yahoo.com
}

\begin{abstract}
This study has a purpose of elaborating the motives of living in a long-distance relationship and finding out the interpersonal communication and communication experience of a long-distance marriage partner if one of them stay in different city (Bandung). The research uses constructivist paradigm method with phenomenology tradition. Data is obtained through in-depth interviews with six informants who undergo long-distance relationship with their respective spouses. The result of this study finds that the motive of getting married for long-distance couples is the motive of cause (because of motive): feeling that they match for each other, the compatibility in communicating and having the same mission/vision in life. While the purpose motive (in order to motive) is gaining support and building a sakinah family. Interpersonal communication in longdistance couples is a commitment built on trust and supporting each other's activities. Happiness is believed to be the power of commitment to marital relationships. The communication experience of long-distance marriage partners is to maintain quality of communication, such as expressing the feeling, asking news, encouraging, supporting, and also praying for each other's success. This is done by utilizing various media the informants have.
\end{abstract}

Keywords: Family Communication, LDR, Motives

\section{Introduction}

Virgiana Satir, an American family therapist, says that a family is a unit of a number of people who live in relation to each other from time to time in the joint living space (in Beebe, 2009: 187). Economic development and educational improvement make the concept of family experiencing an interesting shift to be studied. This shift leaves family members separated for a certain time. In Indonesia, the need for economic and educational life is still centralized in Java and in several big cities in Indonesia. This makes a lot of workers eager to come to the big cities, especially in Java, hoping to get a much better income than in their districts. Similarly, in order to improve quality and educational facilities make many people from outside Java such as Sumatra, Sulawesi, Kalimantan want to continue their studies to a higher level education and choose big cities in Java such as Jakarta, Surabaya, Yogyakarta, and Bandung.
This condition affects the decision on the separation of married couples who have the desire to work in a big city or continue their studies.

The phenomenon of separation of husband and wife for the sake of a better future becomes the focus of interest in this study, especially from the pattern of family communication they do. The relationship made by two unionized individuals in a marriage has to be separated for a while not because there is no feeling of mutual love, but it is because in order to get a better life that makes married couples separated in place.

When a woman meets and interacts with a man who is just as mature as her and she feels that she finds many matches in many ways with that man where later on they agree to commit to a marriage bond, surely this is a kind of a happy ending story, even though a real life actually begins in a family when marriage takes place. The family's 
journey becomes interesting when it faces the dynamic that can start from economic problems, children, big family, helpers, or the distance that separate husband and wife due to work or education.

There are various motives behind a marriage undergone by some couples which also drive some expectations within it. Moreover, they are willing to undergo a marriage even though they live in different place due to work or education. In the study of escalating and maintaining relationship by Steven A Beebe et al, it is said that several factors that can cause disconnection are: time, distance, conflict, and death.

Long Distance Relationship (LDR) is a term occurs to couples who are separated by distance because one of them works in a different city. That is what happens to GG, a civil servant in one city in West Java who survives being alone for about 10 years while his wife and the two children live in Riau Islands. They meet 4 or 5 times in a year but nevertheless, the communication with his wife and his children runs smoothly with the communication tools available today. According to GG, it felt hard in the beginning of the separation when he was accepted to work in Java while the wife who is also a civil servant has been firstly received to work in the ancestral land of the wife's family. But as the time goes by, now GG and his wife also their children are used to such a living except when the children were still toddlers and became sick, that was when the anxiety and the guilt felt.

Long distance relationship is identical with couples whom are separated by physical distance that does not allow physical closeness for a given period of time, and a very limited communication's opportunity in each individual perception whom is undergoing a long distance relationship. The difficulty of communication happens because of the limitations of tools and places which are not strategic to communicate smoothly. LDR is more known at this time by lovers who wove romance with the distance between cities even between islands and or countries. They perform intensive interpersonal relationships using various media to keep the feeling that is intertwined between the two. (Dharmawijati, 2016: 237-248)

Personal relationship is where somebody discloses information to one another and strives to meet one's personal needs (Budyatna, 2011: 36-37). Husband and wife in a relationship always reveal the personal side or thing contained within themselves. It is a private realm that no one else knows but is known by the partner. The context of this established relationship is known as personal relationship. The interpersonal relationship between two individuals is not only intertwined in a close condition but also in a distance which is known as a long distance relationship. LDR can be defined as a relationship between a married man or woman or a committed relationship where the two live separately and they can not meet in person each day because of the distance and time limit. Long distance relationship (LDR) is lived by some people for some reasons such as work, school, or other things.

The LDR actors, according to the concept of family communication, must be very susceptible to a termination due to the distance Here is how some couples make an effort to maintain interpersonal relationships with their partner.

To foster interpersonal relationship in interpersonal communication as stated by Jalaluddin Rachmat, (1996: 129-136) is influenced by three factors: (1) Believing (trust), means that if someone has a feeling that he will not be harmed, will not be betrayed, then that person will more easily open himself. Believing in others will grow when there are factors as follows: characteristics and intentions of others, means that person has the ability, skills, and experience in a particular field. The person is predictable, reliable, honest, and consistent. Power of relationship, means that when a person has power over others, then that person is obedient and submissive. The quality of communication and its nature reflects the openness. When the intent and purpose are clear, hope is expressed, then the attitude of trust will grow; (2) A supportive attitude (supportiveness) which is expected to improve communication. Some characteristics of supportive behavior are: Description: delivery of messages, feelings and perceptions without assessing or criticizing their weaknesses and shortcomings. Problem orientation: communicating the desire for cooperation, looking for problem-solving and inviting others together to set goals and determine how to achieve the goals. Spontaneity: an honest attitude which is considered not to cover the underlying motives. Empathy: regarding others as personal. Equation: not affirming differences, the communication which does not see differences despite 
the status is different, appreciating and respecting for differences in views and beliefs. Professionalism: a willingness to review your own opinion. And (3) Open-mindedness, objective judgment ability, the ability to easily distinguish something, the ability to see the nuance, the orientation to the content, the search for information from various sources, the willingness to change their beliefs, professional, and so on. This open attitude can be contrasted with the character of the person who is being closed with.

This research, which is based on the phenomenon of married couples who undergo LDR, is aimed to explore how communication is established between couples who love each other but separated by distance. How the communication that exists in each family is unique as sequential research conducted by Mary Anne Fitzpatrick and her colleagues which produced the theory of family relationships in his book Between Husband and Wifes: Communication in Marriage 1988 (in Morissan, 2013: 289)

The purposes of this study are to find out the motives of marriage in long distance pairs and To describe interpersonal communication on long distance couples; and 3. To know how communication experiences for the long-distance couples.

\section{Research Method}

This research method uses constructivist qualitative paradigm with phenomenology tradition, that is the research which intends to reveal individual's conscious experience about long distance family communication. Phenomenology is etymologically derived from two words in Greek, phenomenon and logos which means appearance. While Psychology interpret the phenomenon as data from experience that can be observed (Misiak, 2009: 2).

How is the motive behind the couples who must be separated because of the work or for continuing studies to improve the current job career. It is also revealed how the interpersonal communication between long distance marriage couples takes place. The data was collected through in-depth interviews to three husbands and wives as key informants. The selection of three husbands and three wives is done purposively based on predetermined criteria, such as they are husband and wife who live apart between cities because either of them works or continues the studies. In addition, in accordance with the terms of phenomenological research presented by Cresswell (2014), key informants are those who experience and can articulate their conscious experience of living apart from their spouses. The other criteria are those who have been separated from their partners for at least a year so that they have a life experience apart from their spouses for a relatively long period. The six key informants in this study were found in Bandung because they live here to continue their study, while their partners are living outside Bandung or in their hometown.

This research was conducted in Bandung with the argument that Bandung is known as a student city based on the number of universities that become the destination to continue the study. In addition, Bandung is also a city that is chosen as a city of settlement, while the husband works outside Bandung.

Table 1

Profile of The Informant

\begin{tabular}{lllllll}
\hline $\begin{array}{l}\text { Name/ } \\
\text { Status/Age }\end{array}$ & $\begin{array}{l}\text { GG/ } \\
\text { Husband/43 }\end{array}$ & PJ/Wife/43 & SW/Wife/43 & $\begin{array}{l}\text { FN/ } \\
\text { Husband/43 }\end{array}$ & $\begin{array}{l}\text { MP/ } \\
\text { Husband/43 }\end{array}$ & SM/Wife/43 \\
\hline $\begin{array}{l}\text { Spouse's } \\
\text { Occupation }\end{array}$ & $\begin{array}{l}\text { Civil servant } \\
\text { in Bandung/ } \\
\text { Wife in } \\
\text { Pekanbaru }\end{array}$ & $\begin{array}{l}\text { Civil servant } \\
\text { in Bandung/ } \\
\text { husband in } \\
\text { Palembang }\end{array}$ & $\begin{array}{l}\text { Civil servant } \\
\text { in Bandung/ } \\
\text { husband in } \\
\text { Palu }\end{array}$ & $\begin{array}{l}\text { Civil } \\
\text { servant in } \\
\text { Banjarmasin, studying in } \\
\text { studying in } \\
\text { Bandung }\end{array}$ & $\begin{array}{l}\text { Civil servant } \\
\text { in Palu, }\end{array}$ & $\begin{array}{l}\text { Civil servant } \\
\text { in Padang, } \\
\text { studying in } \\
\text { Bandung }\end{array}$ \\
$\begin{array}{l}\text { Age of } \\
\text { marriage/ } \\
\begin{array}{l}\text { Number of } \\
\text { Children }\end{array}\end{array}$ & 13 Years/2 & 6 Years/0 & 14 Years/1 & 13 Years/0 & 8 Years/2 & 10 Years/3 \\
\hline
\end{tabular}




\section{Findings and Discussions}

Informants in this study are to six people selected based on predetermined criteria. To get a closer background and brief information about them as a result of qualitative research by gaining entry or establishing rapport (Alwasilah, 2009: 144), the following profiles of the six informants are presented below:

The table of informants profile above shows the identity that has meaning in the marriage interpersonal relationship. If you look at the age range from 31 to 43 years, it means that they are individuals belong to the productive age both financially and in the relationship of husband and wife where the level of biological needs is at a high level. When it is associated with the age grouping issued lately by $\mathrm{WHO}$, it says that $31-43$ years old are included into youth groups where youth have an identity of spirit and work. Similarly, when it is juxtaposed with the concept presented by BPS who said that a very productive age has the following characteristics: Has a work, Active, Energetic in working, Hard work, Smart work, Be independent, Do not neglect spirituality and religiosity, and Have a life view and forward insight

This shows how these informants are indeed experiencing a quite heavy phase in their lives where they must be separated by the distance when their relationship requires togetherness and unity not only in thought but also in physic. Especially for four couples who have been blessed with children and definitely need a pattern of family education intact from both parents.

Communication is one of the most important keys to build a strong family. Many families are forced to struggle because of poor communication. Family relationships can be weakened by being too busy to work, being indifferent to family needs or never developing an intimate and good communication. We live in a busy world but that does not mean we have to let go of quality communication between husband and wife and between parents and children. The heartbeat of the family is expressed in communication with each other.

GG is a Sundanese, he works as a lecturer at one of public universities in West Java. Besides being a lecturer, GG also now holds a position at the university where he serves. GG married 13 years ago to a woman from Riau, and now they have 2 children.
GG's first meeting with his wife was originally in Jakarta and according to GG, he was introduced by a friend. GG's wife is a doctor who is placed in one of regencies in Riau. During the marriage, GG must undergo a long-distance marriage with the wife because of work factor.

$\mathrm{PJ}$ is a Sundanese, she works as a lecturer at one of public universities in West Java. PJ was appointed as a civil servant in 2015. PJ married to a Sundanese man in 2010. For 6 years of marriage until now, they have not been blessed with a baby. PJ's husband is now working in Palembang so that PJ must undergo long-distance marriage all this time.

SW is a Bugis person, and one of the civil servant lecturers at the Faculty of Social and Political Sciences of Tadulako University in Palu, Central Sulawesi, precisely in Anthropology program. SW married to a Sundanese man in 2003. SW met her husband in the same year where they got married. Initially, SW got acquainted with his spouse via internet and they had never met at all in the real world before but then the couple was committed to get married. SW's husband himself works as a civil servant in West Java. Since being appointed as a civil servant at Tadulako University in Palu, SW has to undergo long-distance relationship with his spouse.

Everyday $\mathrm{FN}$ works as one of the lecturers at Lambung Mangkurat University in Banjarmasin with a civil servant status. FN comes from Banjarmasin. In 2015, FN continued his education in Bandung, so for the last two years FN must undergo long distance relationship with his wife. FN himself married to a Javanese ethnic woman in 2004. Until 13 years of marriage FN with his wife, they have not endowed a baby.

MP is from Bugis, he is one of the lecturers in Communication Studies Program at Faculty of Social and Political Sciences of Tadulako University, Palu, Central Sulawesi. Since continuing education in Bandung in 2013, then for 3 years MP must undergo a long distance relationship with his wife who now lives in Donggala district of Central Sulawesi. MP's wife is a Bugis person who is a civil servant as well. MP with her spouse have been blessed with 2 children. The couple has been married for 8 years.

SM is one of the lecturers at Andalas University in Padang She married to a Bugis 
man in 2006 and they have 3 children. Currently SM is undergoing a long-distance marriage with her spouse because since 2012 SM continues her doctoral education in Bandung.

The age of marriage of key informants can be said to have entered adaptation stage ( 6 to 13 years of marriage age), certainly it is not a short time in a marriage journey with a condition where they have to be far away from each other. They see this long distance relationship differently with some of them convey the positive things of their relationship. They keep missing the spouse and if it is the time to meet, they would be like a newlywed couple. It is conveyed by GG, FN, SM, and MP. Even PJ and GG say that they are rarely in quarrel because the meeting time is very short so it would be a shame to waste the time for quarreling. However, most of them say it is indeed really hard to undergo this long-distance relationship when one of them is ill or the children are ill. In addition, they feel quite burdened from the economic side because there are two kitchens to be financed.

The wishes of the six key informants are the same that they do not want and will not forever be separated by distance. The school, of course, will be finished soon and they will be reunited in one house in one city. While those who are separated because of work, say that they just enjoy the conditions exist, especially with technology that is very supportive to communicate anytime with all family members. The six informants are well aware that the distance that separates them is very vulnerable to the occurrence of something that is not desirable, so they are convinced that one day this must be end and they will gather as a whole family as conveyed by family communication expert, Virgiana Satir.

\section{Married Motives}

Some experts say that a conscious human behavior and actions are always based on motives. Likewise in the act of marriage in long-distance couples, there are always a number of motives underlying, and in this study the researcher categorizes the motives of the informants married with their spouses.

Two of the six key informants of this research have known since before married that they will be separated by the distance in the course of their marriage life so that these two men have prepared themselves to live with it. While other informants undergo a long distance relationship after entering the marriage. Because as a lecturer, the spouse is required to continue study outside the city, as well as when PJ as a wife who certainly does not want to be apart from the husband who works in one of the State-Owned Enterprises (BUMN) and she is placed in Palembang and actually she is turned out to be separated because as a lecturer in Bandung, she has her own obligations at her work.

The motives underlying the informants to get married are divided into 2 groups, namely because of motive and in order to motive. In exploring the because of motive, the researchers see the reasons that make informants take marital action, while in order to motive is obtained by looking at the goal to be achieved by informants in marriage. The results of this study convey that the motives of getting married for informants are: Because they feel match for each other; the compatibility in communicating; and having the same vision and mission in life. Three of the informants of this study believe that God already set everyone's mate, and they feel that their current partner is the one arranged by life to be their soul mate. Furthermore, there is an informant who states that he got married to his partner because of the compatibility in terms communication. Two informants admit that their marriage is based on the same vision and mission in looking at life so that they are sure that they will be happy to live with their partners.

Meanwhile, the goals of the motives are gaining support and building a sakinah family. In life, someone needs someone else who can support in achieving what is desired, and the partner is the person who will be able to support each other both in reaching career and personal life. Most informants said they wanted to build a peaceful family called sakinah family with their partner. This is in line with what William C. Schultz (FIRO-Fundamental Interpersonal Relations Orientation) says that every human being has a social need or is called interpersonal needs, which are: inclusion, control, and affection. This means that every individual basically has the need for others to be part of his life (inclusion). This is what makes a person feel meaningful in life because there is someone who needs him and vice versa. Another requirement is that everyone feels the need to be personally noticed by a particular person who may be a special concern. Many people think it is fun to be free without someone 
organizing, but in fact many people actually feel very happy to have a commitment to someone special even though it contains rules and controls which driving their attitudes and behaviors as a consequence of that commitment. Finally, everyone needs a feeling or emotion that creates comfort from others (affection) as well as being cared and loved. Although in the reality, the relationship in this study, couples who have been united in marriage bonds have to be separated for a while because of circumstances, this is what Morissan calls as sacrifice in relationships (Morissan, 2010: 167).

\section{Interpersonal Communication of Long Distance Couples}

Interpersonal communication is something that is inevitable in the life of every individual, as Richard West and Lynn Turner (Suminar, 2016: 8) say that it is one of the principles of communication that couples in the family do. Even Interpersonal Communication is a very important communication to be studied as Beebe says in the explanation of reasons why this should be learned as an effort to improve relationships with individuals in the family.

The advance in communication technology helps couples to keep communicating. This is felt by the six key informants for keeping the integrity of commitment and sense of mutual care and trust in a marriage. They spend more budget for the cost of 'pulse' than married couples who live in one house because this is one of the solutions to be able to maintain the relationship. Some of them communicate with their spouse with no time rules, which means when they feel necessary they call or send messages via chat, and some are committed to media relations at certain times. We usually communicate at night around 9 o'clock. It is always every day we call to ask each other's conditions and else (PJ 's interview). This is what Stephen D. Perry explains In the Communication Theories: Everyday Life book compiled by John R. Baldwin in the Media chapter: a Tool to Meet Our Needs where individual rejected or accepted as a consequence of the selection of media based on the function of the media in order meet they need. This is described by the term Fraction of Selection. (Baldwin, 2004: 134)

The communication between husband and wife must be honest and open, so that what is desired by each pair can be delivered and not keeping it alone, although in distant conditions. Communication in the family will be established well if each family member is earnestly in giving and receiving information. Through this communication, it is not only intended to tell something but also contained the nature of self-sharing, thoughts, feelings, aspirations and various aspects of life. In the family, communication must be established between husband and wife and between parents and children. Without good communication among family members, effective communication will be far from the expectation.

The uniqueness of human relationships cannot be separated from the role and function of interpersonal communication that is to build contact with others, then provide similarity in the meaning of the message. Interpersonal communication can be developed more widely due to people exchanging their experience. Similarly, in the context of a marriage, the intense communication is a must and cannot be left behind. In interpersonal communication, the response of verbal and nonverbal action and reaction of a person as well as in the family can be seen directly (husband and wife, or child). (Syam, 2015: 419-428)

In a marriage, commitment is one of the most important parts in keeping loyalty to the partner. Commitment is generally defined as a person's intention to maintain a relationship and stay inherent in the psychological matters. Commitment is defined as a strong individual's acceptance to the goal. Commitment is how far individual's long-term orientation experience toward the relationship, including the desire to maintain a better or worse relationship. Individuals with these competencies are prepared to sacrifice their personal goals to achieve greater goals, find goals that are grounded in a great mission, use the fundamental value they have in making decisions, and classifying choices.In a marriage setting, one of the things discussed is marriage commitment, and that individual goal is the purpose of marriage according to the couple. From the opinion above, it states that a happy marriage involves a commitment to the marriage relationship. Commitment is something that is easy to say but requires a tough effort in realizing it in attitude and behavior because it contains priority and sacrifice. When a person enters a marriage relationship, the priorities in life must be changed and different than when 
he was still living without a partner. When husband-wife make a decision to separate for a while because of the distance, it is a decision that has been through a long discussion and even involving children for the couples who have been blessed with children. Some of the informants declared to separate for 2 to 3 years and even more because choosing to continue the study in another city spaced up to hundreds of kilometers is a priority right now for a better life in the future. In fact they say it is a decision to strengthen the commitment to a happy life in the future.

Almost all informants agree that this distance apart is a part of their sacrifice as a couple because it is very unpleasant to be apart. Especially when there are family problems or the children are ill. Feeling of guilt and discomfort are very likely to happen, but this feeling gradually eroded with routine activities, especially for couples who become grantees. Even family problems occurred can often trigger to immediately complete the studies of the informant.

\section{Communication Experience of the Long-Distance Marriage Couples}

Communication between husband and wife is not static but always dynamic. To maintain and reinforce harmonious relationship, it requires certain actions to achieve and maintain balance. There are four factors that are very influential in maintaining balance, namely: familiarity, control, response, and appropriate emotional tone. When the relationship between husband and wife is spaced, the four factors to achieve balance in a harmonious relationship become difficult to do. The existence of communication media into a tool that becomes the foundation of the couples. However, the thing that needs to be anticipated is the character of the media itself that it does not only have the strength but also the weakness that makes the relationship intimacy very limited.

Direct meetings that are rarely found by the LDR couples do not necessarily make the couple get further distanced. This little meeting intensity is best utilized by the couples when they meet, and the meeting time should be used as best as possible and avoid questioning useless matters. Each person feels special with this short meeting.

Family communication involving husband and wife can still be done, which in turn can strengthen the function of the family as a member of institution, especially for growing children (Fatimah, 2014: 199-208) There are some happy moments of these couples when the holiday comes. Three of the six informants who are studying in Bandung at the doctoral level always take home during holidays to gather with the family. Even when the task of study is reduced, they can go back more than once in a year. This is what they feel as a very happy time and they recognize togetherness as a time to communicate with optimal quality because the they do communication directly without any media they usually use during long distance relationships that are often perceived differently than as intended to. Some of them also have experience where couples and even children who live a long way from Bandung can have an opportunity to come and enjoy vacation in Bandung and surrounding areas. They introduce the environment where they study and also special places that exist in Bandung. They also introduce their new friends in Bandung and this is a very supportive thing to build the partner's trust. The experience of returning home during the holidays and the couples visit to Bandung is a very happy opportunity for them, although they admit they must pay a lot for travel cost and so forth that the amount is even drains their savings. However, the expenses they have to incur felt to be a struggle that must be spent to maintain the quality of the relationship with the level of trust of both parties. Love is not cheap indeed, that is one of the phrases that SM said. Another case is GG who always takes time to 'go home' to Riau for family gatherings at least twice a year at Idul Fitri holiday and mid-year school holiday. This father of two children is committed to his family to always gather at the moment of the holiday because he is no longer has any parents, so he feels it is important to gather with his wife and the two children and respect the parents' wife who are still alive and live in Riau. This is as a gratitude for his two parents-in-laws that have helped a lot to keep and pay attention to his children considering he lives far away in Bandung while his wife is working. Although, GG admits that when he comes home to get together with his wife and his children he often uses the chance to be a 'driver' who is always ready to drive the children to wherever they need to go and want. This is a very happy moment because during his stay in Bandung, he can not do it.

Similarly PJ, always takes time to at least once in two months fly to Palembang even for just one or two days. "Alhamdulillah 
now there are direct flights from Bandung to Palembang, I go on Friday and go home on Sunday. It is okay even though it is a little bit expensive since it is more important to meet husband". That is the expression of the 31 years old woman who have married for six years who tells her 'struggle' to maintain a long-distance relationship with her husband. "There was also a time where my husband went to Bandung and get paid by his office because there were tasks. Actually, the task was to transit in Jakarta but it would be unfortunate if he did not go to Bandung because Jakarta is close to Bandung".

LDR will never be a problem as long as both partners can maintain their communication. The communication done is the quality one. Quality communication is the kind of communication which expressing feelings, asking news, encouraging, supporting and motivation and also giving a prayer for mutual success. They are grateful because at this time so many conveniences can be utilized to establish effective and efficient communication.

The long-distance relationship that occurs in these six pairs also experienced some conflicts. Some of them acknowledge misunderstandings in communication, as well as fears of things happening that the couple do not want to be ever revealed. FN, for example, is fully aware that the conflict can happen, "Not just the long-distance partners, those who meet each other and stay at the same house would get the problem which is often not solved immediately. Moreover, we are limited by distance, so when there is a problem, it is rather difficult to solve directly. If there is such a problem, it definitely means the cost of pulses are soaring". They agree that the existence of communication tools that currently exist is very helpful to communicate with spouses and children. This is what until now becomes a powerful weapon for them to control the communication, "yaa ... the risk is that the cost of pulse becomes big during our parting and this becomes a thing that needs to be accepted." That is the expression of some informants when they said there is a time when their children made a call more than five times in a day asking for help doing homework from school.

Communication experience of the informants in this research is maintaining communication that can be done in a long distance condition, in this case is utilizing all media available intensively. The long-distance condition makes couples learn each other the meaning of loyalty and maturity.

\section{Conclusion}

From the results of research that has been done, some conclusions are drawn as follows: There are some motives underlying the long-distance marriage couples: because of motive (cause motive) which is caused by the match, the compatibility, and similarity of vision and mission, while in order to motive (goal motive) is to gain support and form a sakinah family. While interpersonal communication on long-distance marriage couples is done by continuing to build a commitment to their respective spouses, building trust, openness, and mutual support to each other's partner.

As for the communication experience in long-distance marriage couples keeps maintaining the quality communication and as a means for learning. To successfully undergo a long-distance relationship, it takes commitment, openness, mutual understanding, and trust from each partner.

Some suggestions that need to be addressed are: Maximizing the long-distance marriage relationship. It is recommended a further research with different research focuses; Required research related to a political campaign with multi-subject and in the wider scope in order to find models of communication in long-distance marriage couples so that it becomes a reference for a couple who are doing it.

\section{References}

Alwasilah, A. Chaedar. (2009). Pokoknya Kualitatif: Dasar-dasar Merancang dan Melakukan Penelitian Kualitatif. Jakarta: Dunia Pustaka jaya

Baldwin, John R. Stephen D. Perry and Mary Anne Moffitt (2004). Communication Theories: For Everyday Life. Amazon.

Beebe, Steven A. Susan J. Beebe and Mark V. Redmond. (2009). Interpersonal Communication Relating To Others, 6th ed. Allyn \& Bacon, Needham Heights, MA.

Budyatna, M dan Ganiem, L.M. (2011). Teori Komunikasi Antar Pribadi. Jakarta: Kencana

Cresswell, John W. (2014). Peneltian Kualitatif \& Desain Riset: Memilih di Antara Lima

Pendekatan (Terjemahan), Pustaka Pelajar. Yogyakarta 
Dharmawijati, Ratna Dyah. (2016). Komitmen Dalam Berpacaran Jarak Jauh Pada Wanita

Dewasa Awal, eJournal Psikologi, Volume 4 Nomor 2, 237-248

Fatimah, Jeanny Maria, (2014). Komunikasi Keluarga Meningkatkan Akses Pendidikan Bagi

Kesetaraan Anak Perempuan Dalam Lingkaran Kemiskinan. Jurnal Mimbar Volume 30 No. 2

Misiak, Henryk dan Virginia Staudt Sexton. (2009). Psikologi Fenomenologi, Eksistensial dan Humanistik - Suatu Survey Historis. (Terj). Bandung: Refika
Aditama.

Morissan, (2010). Psikologi Komunikasi. Bogor: Ghalia Indonesia.

Morissan, (2013). Teori Komunikasi: Individu Hingga Massa. Jakarta: Kencana Predana Media.

Rakhmat, Jalaluddin. (2005). Psikologi Komunikasi. Remaja Rosdakarya. Bandung

Suminar, Jenny Ratna. (2016). Komunikasi Antarpribadi. Bandung: Unpad Press.

Syam, Nia Kurniati dkk. (2015). SimbolSimbol dalam Komunikasi Keluarga Beda Agama, Jurnal Mimbar Volume 31 No.2 